\title{
Urban Planning Goes Rural
}

Conceptualising the "New Village"

David Bray

\section{CpenEdition}

\section{Journals}

Electronic version

URL: http://journals.openedition.org/chinaperspectives/6273

DOI: 10.4000/chinaperspectives.6273

ISSN: 1996-4617

\section{Publisher}

Centre d'étude français sur la Chine contemporaine

\section{Printed version}

Date of publication: 1 September 2013

Number of pages: 53-62

ISSN: 2070-3449

Electronic reference

David Bray, « Urban Planning Goes Rural », China Perspectives [Online], 2013/3 | 2013, Online since 01 September 2016, connection on 28 October 2019. URL : http://journals.openedition.org/ chinaperspectives/6273; DOI : 10.4000/chinaperspectives.6273

(C) All rights reserved 


\title{
Urban Planning Goes Rural
}

\author{
Conceptualising the "New Village"
}

DAVID BRAY

\begin{abstract}
A major goal of the national program to Build a New Socialist Countryside is to modernise and urbanise the rural built environment. This objective has been bolstered by the extension of state-sponsored urban planning regimes into rural jurisdictions. One of the implications of this is that every administrative village in China is now required to commission and implement a 20-year "master plan" for redevelopment. Through tracing the origins and rationale of key policy initiatives, in the first part of this paper I aim to show how urban planning came to be seen as an appropriate tool for solving a range of intractable rural "problems." In the second part of the paper, I present a case study of village redevelopment in order to illustrate how the principles of urban planning have been applied to the re-making of rural built environments and the transformation of rural life.
\end{abstract}

KEYWORDS: rural urbanisation, urban planning, built environment, rural social change.

\section{Introduction: How to re-design a village}

L iuxian Village is fairly typical of villages on the plains of northern China, ${ }^{(1)}$ a cluster of single-storey brick homes enclosed by walled courtyards and surrounded by an expanse of flat, dry farmland. Recently, however, efforts have been made to improve the built environment: roads have been sealed, the walls that line the main street have been uniformly painted in pale yellow with dark red trim, neat rows of young trees have been planted along the roadside, and a new "cultural square" has been created in the centre of the village complete with stage, brightly coloured exercise equipment, and an engraved marble monument that tells the history of the village on one side and on the other side lists the donors who financed construction of the square. It turns out that Liuxian Village has done quite well economically: two local factories (formerly village-owned enterprises) - one that produces rotary saw blades and another that manufactures fireworks - have become large and successful private enterprises employing around 600 of the village's 1,800 residents. The other advantages enjoyed by this village are its close proximity to a busy and rapidly growing market town - providing outlets for its goods and additional business and employment opportunities for its residents - and the fact that village land borders the Beijing-Shenyang Freeway, thus offering good transport links to major cities.

But Liuxian Village also has lots of shortcomings - at least this is the verdict of the urban planners who were hired to draft a new plan for village redevelopment through to 2020. According to their analysis, the main problems are:

1. The village residential area is too big, resulting in a serious waste of land;

2. The dispersed village layout is not conducive to the installation of public infrastructure and facilities;

3. The functional zoning of village land is chaotic: aquaculture, industry, housing, and public facilities are all mixed together;
4. The current land-use arrangements are not conducive to the future development of any productive sectors;

5. The village has too many dead-end roads, and transport flow has been neglected;

6. There is no effective landscaping in most parts of the village. (2)

The key to solving problems 1-4 is to implement a radical program of land-use zoning, as the planners explain: "Through rearranging the current industry and land resources, we will create four concentrated functional zones: an aquaculture and fishing zone in the north; a processing and manufacturing zone in the centre; a green agricultural zone in the south; and a residential and public service zone in the east." "(3) The eastern zone, namely the new Liuxian Village, retains some parts of the old village (renovated and modernised) but also requires the demolition of a large section of the village to make way for a new high-rise housing estate and to return land to other productive purposes. According to the plan, where the old sprawling horizontal village occupies around $30 \%$ of total village-controlled land, the new, partially vertical village footprint will occupy only $10 \%$, reducing the builtup area of the village to one-third of its original size. The overall amount of agricultural land will remain about the same as now, so the land reclaimed through shrinking the village will mostly be used to expand non-agricultural industries, with the principal objective of providing more local employment opportunities for villagers as well as developing the local economy.

Problems 5 and 6 simply require some additional investment in roads and landscaping. While better roads might promote economic development, the imperative for landscaping seems a good deal less apparent. But the significance of landscaping is revealed when we consider the underlying logic of village redevelopment. The planners of Liuxian Village claim that their

1. This description is based on my visit to the village in November 2009. All the data and master plan materials discussed below were collected then.

2. Liuxianzhuang, Liuxianzhuangcun xin minju guihua 2009-2020 (Liuxian Village new housing plan 2009-2020).

3. Ibid. 


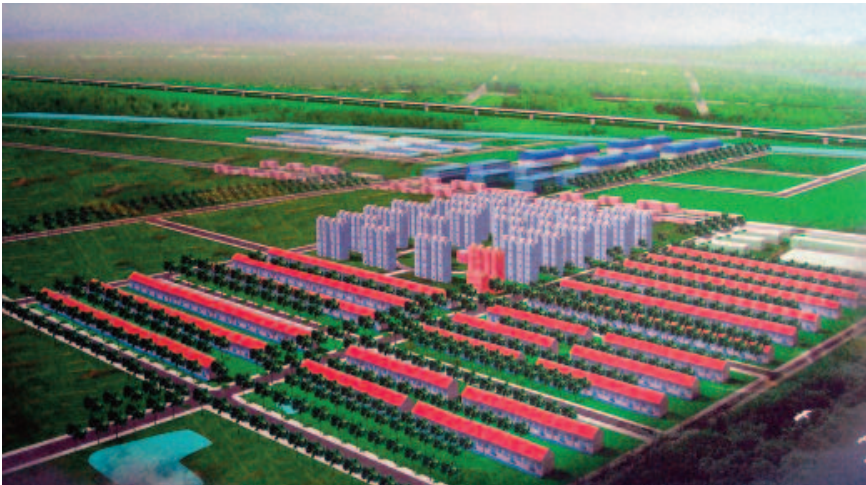

Photo 1 - Artist's impression of Liuxian Village, circa 2020. Source: author's photograph of public display board.

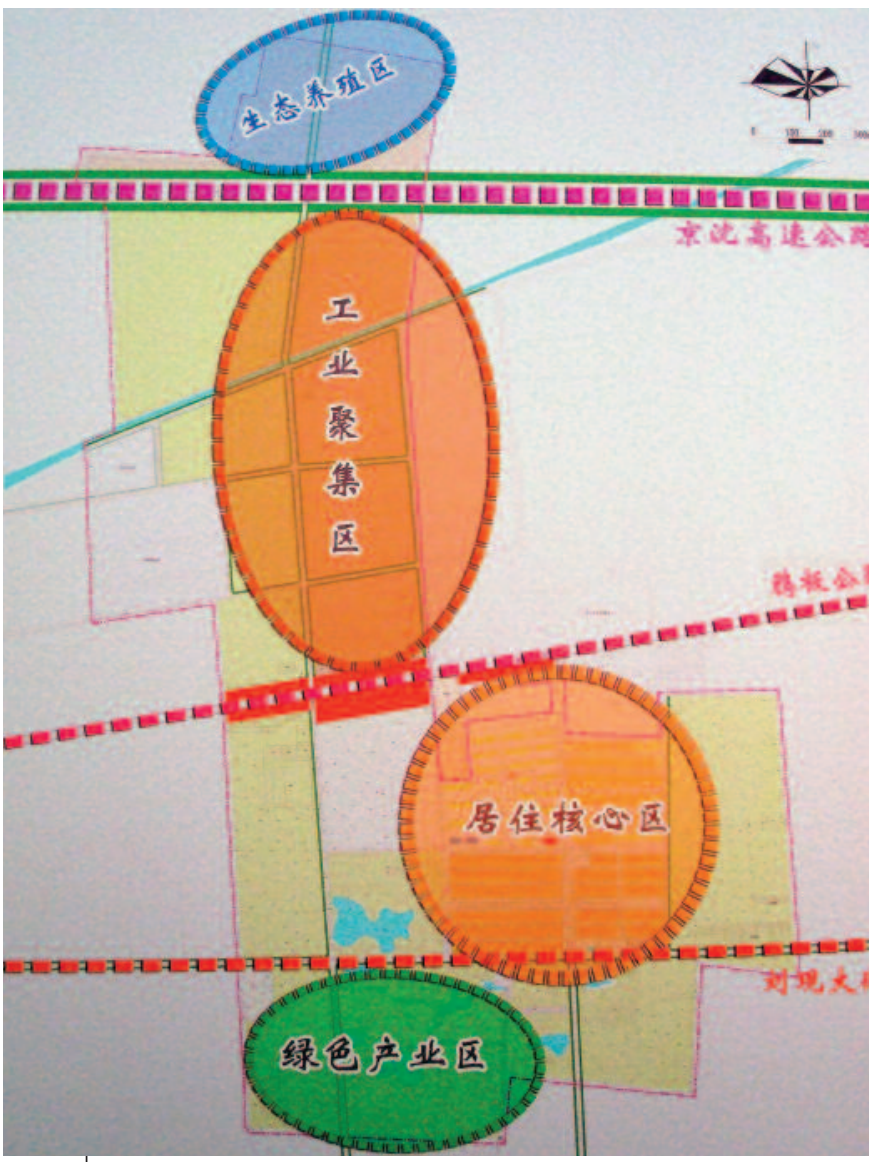

Photo 2 - New functional zoning scheme for Liuxian Village. Source: author's photograph of public display board.

broader objective is to promote "urban and rural integration" (cheng-xiang yitihua 城乡一体化) and "the transformation of farmers into urbanites" (nongmin shiminhua 农民市民化), and that this will be achieved through "building a new countryside that is comfortable, harmonious, and civilised." (4) This redevelopment project, therefore, is not just about enhancing the economic efficiency and productivity of the village and lifting the incomes of its residents. It is designed to be a coordinated and comprehensive program for urbanising the village and transforming its residents. Landscaping seems critical to this "civilising" project because it is understood to mark the difference between a rural and an urban built environment. Land- scaping signifies the intervention of culture into the hitherto "natural" and prosaic rural environment. Landscaping a settlement clearly demarcates the boundary between social and cultural life on the one hand and agricultural and industrial production on the other hand. Just as China's cities have been spatially restructured and landscaped in recent years to separate working space from social and cultural space (witness the demise of the danwei and the rise of the landscaped housing estate or xiaoqu), so rural China is beginning to realise the same logic of "civilisation" through functional zoning and soft landscaping.

At first glance the plan for Liuxian Village may seem unrealistic and extravagant - even utopian. However, a quick survey of rural China will demonstrate that this is not merely an isolated project dreamed up by ambitious local officials. Rather it is one of many thousands of such projects that have emerged throughout rural China in recent years under the national program to Build a New Socialist Countryside (jianshe shehui zhuyi xin nongcun 建设社会主义新农村). ${ }^{(5)}$ The push to modernise and reconstruct rural China has been bolstered by the extension of urban planning into the countryside: in 2007 the Urban Planning Law (chengshi guihua fa 城市规划 法), originally issued in 1990, was revised and reissued as the Urban and Rural Planning Law (chengxiang guihua fa 城乡规划法) in 2007. ${ }^{(6)}$ As a result, the principles and practices of urban planning began to be formally applied to rural as well as urban areas. The most far-reaching implication of this change is that every administrative village in China is now required to commission and implement a 20-year "master plan" for redevelopment.

The key features of the Liuxian Village plan - functional zoning, concentration of resources, landscaping, high-rise living - underscore the extent to which core principles of modernist urban planning are now being applied to these rural redevelopment projects. But this trend should not be read as a simple or straightforward transfer of planning techniques and practices from one realm to another. In fact, a range of initiatives in rural planning had been pioneered in various localities long before the new planning law was issued. It would be more accurate to say, therefore, that the concepts that underpin contemporary planning of village redevelopment have emerged through the marriage of two quite separate governmental discourses: a discourse of urban planning, with a genealogy that can be traced back through PRC history to the Soviet Union and to the origins of modernist planning in Europe and America; (7) and a discourse focussed on problems of rural development in China, which can be traced back at least to the Republican era, and which has generated considerable debate in recent years under the rubric of "the three rural problems" (sannong wenti 三农问 题.). ${ }^{(8)}$

In the first part of this paper, I show how these two discourses came together through key regional initiatives that sought to solve particular "rural

4. Ibid.

5. Minzi Su, China's Rural Development Policy: Exploring the "New Socialist Countryside," Boulder, First Forum Press, 2009.

6. State Council, Zhonghua renmin gongheguo chengxiang guihuafa (People's Republic of China Urban and Rural Planning Law), Beijing, 2007. The revised law was passed by the National People's Congress in late 2007, but only came into effect from the beginning of 2008.

7. For a genealogy of this discourse see David Bray, Social Space and Governance in Urban China: The Danwei System from Origins to Reform, Stanford, Stanford University Press, 2005, pp. 66-93 and pp. 123-156.

8. See Stig Thøgersen, "Revisiting a Dramatic Triangle: The State, Villagers, and Social Activists in Chinese Rural Reconstruction Projects," Journal of Current Chinese Affairs, Vol. 38, No. 4, 2009, pp. 9 33; and Lei Guang, "Bringing the City Back In: The Chinese Debate on Rural Problems," in Martin King Whyte, One Country, Two Societies: Rural-Urban Inequality in Contemporary China, Cambridge MA, Harvard University Press, 2010, pp. 311-34. 
problems" through the intervention of urban planning. The second part describes a case study based on fieldwork undertaken in rural Jiangsu, in order to illustrate how this hybrid discourse of village re-building operates in practice and the impact of its implementation on the social and spatial structure of a rural community. In the conclusion to this paper I situate my findings within the wider literature as I agree with Ahlers and Schubert that the program to Build a New Socialist Countryside is far more than just another political slogan. But, whereas they suggest that the focus on accelerated urbanisation "mimics the historical experiences of Europe and industrialised East Asia," (9) I argue that both the discourses and the contemporary practices of rural spatial planning and urbanisation have unique and specific features that cannot be understood through a European or East Asian perspective. Indeed, my research shows that this program has initiated significant redevelopment of rural built environments, and as a result has had far-reaching impacts on the everyday lives of rural citizens. My objective is not to make normative judgements on the "success" or otherwise of these transformations, nor is it to offer advice on how to "improve" the program. Rather, I seek to explain the background and logic of these initiatives and to flag some of the social implications.

\section{New foundations for rural planning: The "three concentrations"}

Jiangsu Province has played a major role in pioneering rural development in recent years. Famous for its "Sunan (苏南) model" of collectively operated rural enterprises, ${ }^{(10)}$ jiangsu was among the first provinces to develop strategies for coordinating industry and agriculture in rural areas. With expanding rural industry but limited rural land, and with concerns over food security at both provincial and national levels, it is easy to understand how the need for spatial planning of the countryside came to be seen as imperative. While the 1986 Land Management Law required all of China's jurisdictions to increase oversight of land use, especially in relation to the preservation of "primary farmland" (jiben nongtian 基本农田), Jiangsu went further with the development of strategies designed to compensate for farmland lost to industry by creating additional farmland. This was to be implemented by reducing the spatial footprint of rural settlements. In provincial regulations issued in 1994, local rural authorities were enjoined to:

Rationally arrange the layout of housing, village enterprises, public infrastructure, and services; amalgamate dispersed natural villages and progressively build modern villages that are more concentrated and that possess a full complement of infrastructure; encourage rural industry to concentrate into industry parks and provide land for further development. ${ }^{(11)}$

By the mid-1990s, this strategy of "concentrating" rural settlements and industry had been incorporated into a provincial master plan with specific targets. It called for the province's 289,000 "natural villages" (ziran cun 自 然村) to be consolidated into 20,330 "central villages" (zhongxin cun 中心 村) and 31,100 "basic villages" (jiben cun 基层村). If realised, this plan would reduce the amount of rural land used for residential purposes by about $50 \%$, thereby releasing around three million $m u\left(2,000 \mathrm{~km}^{2}\right)$ of land for productive uses. ${ }^{(12)}$ But the plan was not just about saving farmland. It also introduced rural land zoning to create buffers between agriculture and industry, entailing a much higher degree of spatial planning. Henceforth, issues of eco- nomic development, land use management, and rural settlement location had to be considered together through coordinated planning, and through a jurisdictional hierarchical system stretching from the province down through cities, counties, towns, and rural townships. ${ }^{(13)}$

Jiangsu Province's neighbour, Shanghai Municipality, also pioneered new ways to coordinate planning across urban, semi-urban, and rural territories. While Shanghai is best known over the last two decades for the redevelopment and expansion of its core urban territory, including the spectacular emergence of Pudong skyscrapers, Shanghai authorities have also invested considerable efforts into the spatial restructuring of the municipality's outerlying rural hinterlands. (14) Even more than Jiangsu, Shanghai faced the problem of how to reconcile rapidly developing rural industry with the imperative to retain and protect primary farmland. In response to this conundrum, Shanghai authorities followed Jiangsu's lead in promoting the consolidation of the rural population into larger, more compact settlements and through the concentration of rural factories in industrial zones. But they also went a step further than Jiangsu: encouraging farmers to amalgamate their farmland (through various cooperative or shareholding mechanisms) into larger farms in order to improve productivity. Around 1995, this suite of rural restructuring policies gained official designation as the "three concentrations" (sange jizhong三个集中). ${ }^{(15)}$

In 2003, when the central government launched its new policy requiring "coordinated planning of urban and rural development," (16) Shanghai responded by revamping its existing program for rural restructuring and integrated it with its larger municipal master plan. First it released a new guiding document whose stated goals were now far more ambitious: namely, to promote "urban and rural integration," rural urbanisation, agricultural modernisation, and "the transformation of farmers into urbanites." (17) To support these ambitious goals and to accelerate sub-urban integration, the document called for the rapid provision of essential infrastructure, facilities, and services, including roads, transport, water, natural gas, electricity, communications, sewerage, garbage collection, health care, education, culture, sports and entertainment, parks, shops, banks, and post offices. In short, the "three concentrations" were now conceived as a strategy to bring urban standards of living to the countryside. To achieve this, traditional villages would be demolished and replaced by larger scale, fully serviced, residential

9. Anna L. Ahlers and Gunter Schubert, "'Building a New Socialist Countryside' - Only a Political Slogan?" Journal of Current Chinese Affairs, Vol. 38, No. 4, 2009, pp. 35-62.

10. Kellee S. Tsai, Capitalism Without Democracy: The Private Sector in Contemporary China, Ithaca, Cornell University Press, 2007, pp. 156-58.

11. Jiangsu Provincial People's Congress, Jiangsusheng cunzhen guihua jianshe guanli tiaoli (Jiangsu provincial regulations for the management of planning and construction in villages and towns), Nanjing, 1994, Article 5.

12. Yi Zhang, "Liangquan jueze - ji Jiangsu cunzhen jianshe yu jiben nongtian 'liangqu' guiding" (Two choices - record of Jiangsu village and town construction and the establishment of "two areas" of primary farmland), Renmin ribao, 18 July 1997.

13. Guohui An, Erdong Zhang, and Yunmei An, Cunzhuang guihua yu guanli (Village planning and management), Beijing, Zhongguo nongye chubanshe, 2009, p. 47.

14. T.G. McGee, G. Lin, A. Marton, M. Wang, and J.Wu, China's Urban Space: Development Under Market Socialism, London, Routledge, 2007, pp. 121-41.

15. Yishao Shi and Bixia Yang, "Shanghai jiaoqu shishi 'sange jizhong' zhanlue de fansi ji duice jianyi" (Reflections on and countermeasures against implementing the strategy of "three concentrations" in suburban districts of Shanghai), Tongji daxue xuebao (shehui kexueban), Vol. 15, No. 6, 2004, pp. 7-12.

16. One of "The Five Types of Coordinated Planning" (wuge tongchou 五个统筹) first enumerated in the key document issued by the 3rd Plenum of the 16th Central Committee in October 2003.

17. Shanghai Municipal Government, "Guanyu qieshi tuijin 'sange jizhong' jiakuai shanghai jiaoqu fazhande guihua gangyao" (Plan for implementing "the three concentrations" to accelerate development in Shanghai suburbs), Shanghai, 2004 
settlements. This approach was subsequently endorsed by central government authorities. In a key national document on design standards for rural reconstruction, issued in 2006, implementation of the "three concentrations" is recommended for all areas with "comparatively dense" rural populations. ${ }^{(18)}$

In 2006, Shanghai authorities unveiled a new-look master plan to guide future development. Known as the "1-9-6-6 Urban System," it conceptualises Shanghai's entire administrative territory as a coordinated spatial system with four tiers of settlement comprising one central city (zhongxincheng 中心城), nine "new cities" (xincheng 新城), 60 "new market towns" (xinshizhen 新市镇) and 600 "central villages" (zhongxincun 中新 村). ${ }^{(19)}$ At the time it was released, the Municipality of Shanghai still had 109 towns (zhen) and 1,862 administrative villages under its jurisdiction. (20)

Shanghai's "1-9-6-6" plan was particularly significant because of the way it combined a hitherto diverse collection of planning and development policies into a single coordinated scheme, which amounted to a gradated urban system that extended across the entire continuum of urban and rural territory. In sum, not only did Shanghai authorities revamp rural planning through the "three concentrations" initiative, but they also linked this to a small town urbanisation strategy and incorporated both into master planning for the entire metropolis. In this respect, the "1-9-6-6" plan established the conceptual framework of "urban and rural integration" (21) on which the new national planning law was to be based.

\section{Zhejiang pioneers "village planning"}

In mid-2003, authorities in Zhejiang launched a pilot rural redevelopment program known as "One Thousand Model Villages, Ten Thousand Renovated Villages" (qiancun shifan, wancun zhengzhi 千村示范, 万村整治). The broad objectives of this program were to upgrade village public services and infrastructure and to remediate the problem, as they phrased it, of rural environments being "dirty, chaotic, and backward" (zang, luan, cha 脏, 乱, 差). (22) To provide a specific direction for implementing this program, the Provincial Bureau of Construction issued a document entitled (Trial) Guidelines for Drafting Village Plans. ${ }^{(23)}$ It was the first time in China that a "village plan" (cunzhuang guihua 村庄规划) was officially recognised as a distinct branch of spatial planning in its own right.

According to Zhejiang provincial authorities, in the first five years of the program, 1,181 villages were transformed into "all-round moderately affluent model villages" (quanmian xiaokang jianshe shifan cun 全面小康建设 示范村) while another 10,303 villages underwent "environmental rehabilitation" (huanjing zhengzhi 环境整治). (24) In total, around one in three administrative villages in Zhejiang participated in the program, although only one tenth benefited from the full redevelopment package. ${ }^{(25)}$ Despite this limited coverage, Zhejiang's rural initiative was ground-breaking. Not only did it anticipate the national program to Build a New Socialist Countryside by over two years, it also pioneered technical standards and practices for renovating and reconstructing village settlements. Within a year, other provinces picked up the experiments in Zhejiang: Jiangsu and Jiangxi in 2004, Beijing and Liaoning in 2005. (26) In August 2005, the Ministry of Construction sent a high-level delegation, led by its Minister, to study the program in Jiangxi. Following its favourable report to the State Council, village redevelopment was included as a key component when the national program to Build a New Socialist Countryside was announced in October 2005. (27)
Just as conceptual innovations such as the "three concentrations" first appeared within provincial jurisdictions (Jiangsu and Shanghai), so moves to initiate systematic spatial planning at the village level emerged from experimental trials undertaken in a few provincial locations. Prior to this, the village was seen as simply a minor subset of town (zhen 镇) planning. But with the emergence of new urbanisation policies focused on "small cities and towns," the town came to be understood as an urban rather than rural domain, and regional authorities recognised the need to develop a separate conception of the village as a distinct form of built environment.

In 2008, the concept of the "village plan" was given definitive legal status under the new Urban and Rural Planning Law. Previously covered by a range of piecemeal national and local regulations, spatial planning for villages as well as towns and townships has now been brought into the mainstream of national spatial planning law. ${ }^{(28)}$ This makes them subject to two kinds of coordinated planning: first, each is required to produce a long-term master plan setting out land use, functional zoning, infrastructure provision, transport development, and environmental protection within its territory for the following 20 years; and second, each becomes subject to "strategic" regional plans (quyu guihua 区域规划) developed at higher government levels. For example, each province is required to draft a strategic "urban system plan" (chengzhen tixi guihua 城镇体系规划) that sets out the relationships between all cities, county towns, towns, and rural townships. (29) Similarly, at the town level, each jurisdiction has to devise a strategic "town and village location plan" (zhencun buju guihua 镇村布局规划, also referred to as zhenyu guihua 镇域规划) (30) that establishes the future number, location, and relationships between the various administrative and "natural" villages within this territory. ${ }^{(31)}$ The strate-

18. Chinese Academy of Architecture and Design, Xin nongcun jianshe cunzhuang zhengzhi jishu daoze (Technical guidelines for village renovation in building a new countryside), Beijing, 2006.

19. Xiaobo Bo, "Shanghai shiyiwu guihua liangdian: 1-9-6-6 siji chengzhen tixi kuangjia" (A bright spot in Shanghai's 11 $11^{\text {th }}$ 5-Year Plan: 1-9-6-6 four-tier urban framework), Wenhuibao, 5 February 2006.

20. Shanghai Bureau of Statistics, Shanghai Statistical Yearbook 2007, Shanghai, 2007.

21. "Urban and rural integration" does not necessarily imply that the rural people being "integrated" will have their hukou status automatically transferred from rural to urban. It can just mean moving into urban-style housing, and/or shifting to non-agricultural employment. Moreover, depending on the specific context and circumstances, it can be a voluntary or a coercive process. This terminology has now become common, as the earlier Liuxian Village example demonstrates.

22. Aguo Xia, Fengyu chunqiu kan xiangcun: Zhejiangsheng "qiancun shifan, wancun zhengzhi" gongcheng wunian huimou (The countryside through seasons and years: reflecting on five years of the Zhejiang Province program for "One Thousand Model Villages; Ten Thousand Renovated Villages"), Hangzhou, Zhejiang keji chubanshe, 2009, p. 2.

23. Zhejiang Bureau of Construction, Zhejiangsheng jiansheting cunzhuang guihua bianzhi daoze (shixing) (Zhejiang Bureau of Construction [trial] guidelines for drafting village plans), Hangzhou, 2003.

24. Aguo Xia, Fengyu chunqiu kan xiangcun, op. cit. p. 2.

25. Zhejiang Bureau of Statistics, Zhejiang Statistical Yearbook 2006, Hangzhou, Zhejiang Provincial Government, 2006

26. Ming Fang and Aiyun Shao, Xin nongcun jianshe cunzhuang zhili yanjiu (Research on managing village construction for the new countryside), Beijing, Zhongguo jianzhu gongye chubanshe, 2006; Aiyun Shao and Hui Zhao, Xin nongcun cunzhuang zhengzhi guihua shili (Examples of village renovation plans for the new countryside), Beijing, Zhongguo shehui chubanshe, 2006.

27. Ming Fang and Jun Liu, Xin nongcun jianshe: zhengce lilun wenji, op. cit. p. 180.

28. State Council, Zhonghua renmin gongheguo chengxiang guihuafa, op. cit. Article 2

29. Ibid. Article 13.

30. These terms are not mentioned in the law itself, but derive from Ministry of Construction directives on how to implement the law; the terms appear in all the town-level master plans that I have examined during fieldwork in various rural locations of Hebei, Jiangxi, and Jiangsu.

31. Villages in China can vary enormously in size from tiny hamlets of a few households to large settlements of several thousand people. To address this problem of scale, the national authorities developed the concept of "administrative villages" (xingzhengcun 行政村), which, as the term suggests, are the basic administrative units of rural China, each governed by a "village committee" of officials and a Communist Party branch. A so-called administrative village may include any number of smaller "natural villages" (zirancun 自然村). 
gic plans provide broader levels of regional and national coordination, because they link each territorial jurisdiction to its neighbouring jurisdictions and to the wider development strategies of superior jurisdictions. When a town begins to draft its own master plan, for example, it must ensure that its development plans conform to the strategic plan already established by the county and city governments to which it is subordinate.

In the preceding section I have shown how concepts from urban planning have been increasingly employed to address problems of rural development in key provincial jurisdictions over the last two decades. In Jiangsu the expansion of rural industry led to concerns over the preservation of farmland and hence the decision to adapt "rational" urban planning principles to the organisation of rural land usage. As a result, authorities began to enforce spatial zoning to separate farmland from industrial and residential areas. Municipal leaders in Shanghai expanded on these initiatives to integrate its rural hinterland into a coordinated spatial hierarchy that extended the principles of urban planning across the entire municipality. In Zhejiang, the coordinated planning of rural space was further enhanced through the development of specific technical standards for the renovation, re-design, and re-construction of village settlements. Here the intervention was justified as a response to a decaying rural environment characterised as "dirty, chaotic, and backward."

It has been through these provincial initiatives that the discourses of urban planning and the discourses of rural rejuvenation have inexorably come together, culminating in the incorporation of rural territory into the formal government regime of spatial planning. Thus, for the first time, rural settlements have come under the same legal planning framework as cities. ${ }^{(32)}$ The objective with this initiative is not only to use urban planning as a mechanism for controlling rampant over-development and for preserving farmland, but also for promoting modernisation of the built environment in those parts of rural China that remain under-developed. The application of urban planning concepts, expertise, and processes to rural China has become a significant component within the larger program to Build a New Socialist Countryside, and has clearly led to the emergence of a new mode and new phase of urbanisation. In the following section of this paper I explore some of the parameters of rural urbanisation through a case study of village redevelopment.

\section{The Qinglong master plan ${ }^{(33)}$}

Qinglong is an administrative village in Jiangsu Province located $22 \mathrm{~km}$ southeast of Nanjing's city centre. In 2006, when its new master plan was first drafted, it had around 1,080 households and a total population of just over 3,200 people spread over 14 separate natural villages ranging in size from 16 to 145 households. The village controls a territory of $10 \mathrm{~km}^{2}$, including fertile river flats used for grain and vegetable production, areas of low hills covered in tea plantations, and a more rugged hilly area to the north, which is mostly forested but also has some small quarries.

Historically Qinglong has always been under the jurisdiction of Chunhua Town, ${ }^{(34)}$ which was itself subordinate to Jiangning County. In 2000, the county was converted to a district under Nanjing City; then in 2004, the official designations of the subordinate administrative jurisdictions were also "urbanised," such that Chunhua Town (zhen) became Chunhua Subdistrict Office (jiedao banshichu 街道办事处) and Qinglong's designation was changed from "village" (cun 村) to "neighbourhood community" (shequ 社 区). Since the early 1990s, the term "community" had gradually been adopted to designate the basic administrative unit within urban areas, formerly known as the Residents' Committee (jumin weiyuen hui 居民委员会), but had never been used in reference to rural settlements. ${ }^{(35)}$ While Qinglong is relatively close to Nanjing City, and parts of Jiangning have merged into Nanjing's urban sprawl, Qinglong itself remains largely rural, with the vast majority of its land still under agricultural production. The decision by Nanjing authorities to apply urban jurisdictional terminology to almost all its subordinate territories, including those that remain largely rural, seems to have been one response to the central government directive calling for the integration of urban and rural areas. (36) But when we examine the Qinglong master plan, we will see that this change in nomenclature was not simply a superficial semantic shift. Rather, it signalled the beginning of a whole range of substantive redevelopment initiatives designed to provide the residents of Qinglong with services, infrastructure, and a built environment that resembled those available to Nanjing's urban residents. Indeed, the 2006 edition of the Jiangsu Provincial Guidelines for Village Planning and Construction states that one of the key objectives of village redevelopment is to "promote the extension of urban civilisation into the countryside." (37) In 2006, Qinglong was chosen by the Jiangning District Government to be one of four district-level "high-standard trial sites" (gao biaozhun shifan dian 高标准示范点) for Building a New Socialist Countryside. (38) The District Construction Bureau then commissioned planners from the jiangsu Academy of Planning and Design to draft master plans for each of the four trial village sites. Qinglong's plan was approved (39) for implementation in October 2006. ${ }^{(40)}$ The plan is formally entitled Qinglong Community New Countryside Construction Plan, and is divided into three sections respectively titled: "Master Plan," "Donglong Central Village Short-term Renovation Plan," and "Donglong Central Village Long-term Renovation Plan." The first section covers land-use and economic development for the entire territory, while the second and third sections outline a two-part program for the renovation and redevelopment of Qinglong's largest natural village, Donglong, which had long been host to the administrative and Party headquarters for Qinglong. The new master plan seeks to build on this existing role and enhance

32. Xingqing Ye, "China's Urban-Rural Integration Policies," Journal of Current Chinese Affairs, Vol. 38, No. 4, pp. 117-143.

33. The following discussion is based on materials (documentary and oral) collected during four separate research visits (totalling seven days) to Qinglong since 2008. Thanks to Professors Zhang Yulin and Zhou Xiaohong, Department of Sociology, Nanjing University, for organising the visits; and to my former doctoral student, He Hongguang, for providing logistical and research assistance. I am grateful to Qinglong authorities, especially Deputy Party Secretary Wang Chunling, for local assistance, access to documents, and willingness to answer my numerous questions. This case study is not intended to be a comprehensive ethnography of the village; rather, the fieldwork was focussed on the development and implementation of the master plan and how this intervention has transformed Qinglong's built environment.

34. Like most rural jurisdictions of its status, Chunhua's administrative designation has changed several times since 1949: from "township" to "people's commune," back to "township," then to "town," and most recently to "subdistrict office."

35. David Bray, "Building 'Community': New Strategies of Governance in Urban China," Economy and Society, Vol. 35, No. 4, 2006, pp. 530-549.

36. On the adaptation of concepts such as "community" and "community building" to rural contexts, see Lior Rosenberg's paper in this issue.

37. Jiangsusheng cunzhuang jianshe guihua daoze (shixing) (Jiangsu Province [trial] guidelines for village planning and construction), Nanjing, 2006, Section 1.5.1.

38. Jiangning District, Jiangningqu jianshe gao biaozhun xin nongcun shifandian gongzuo fang'an (Jiangning District work program for constructing high standard new countryside model villages), Nanjing, 2006.

39. According to provincial regulations, the master plan must first be assessed and approved by an "expert" panel including registered planners, then it is submitted to the village congress (or representative congress) for approval, and finally must gain formal authorisation from the town/township/subdistrict office level of government. 


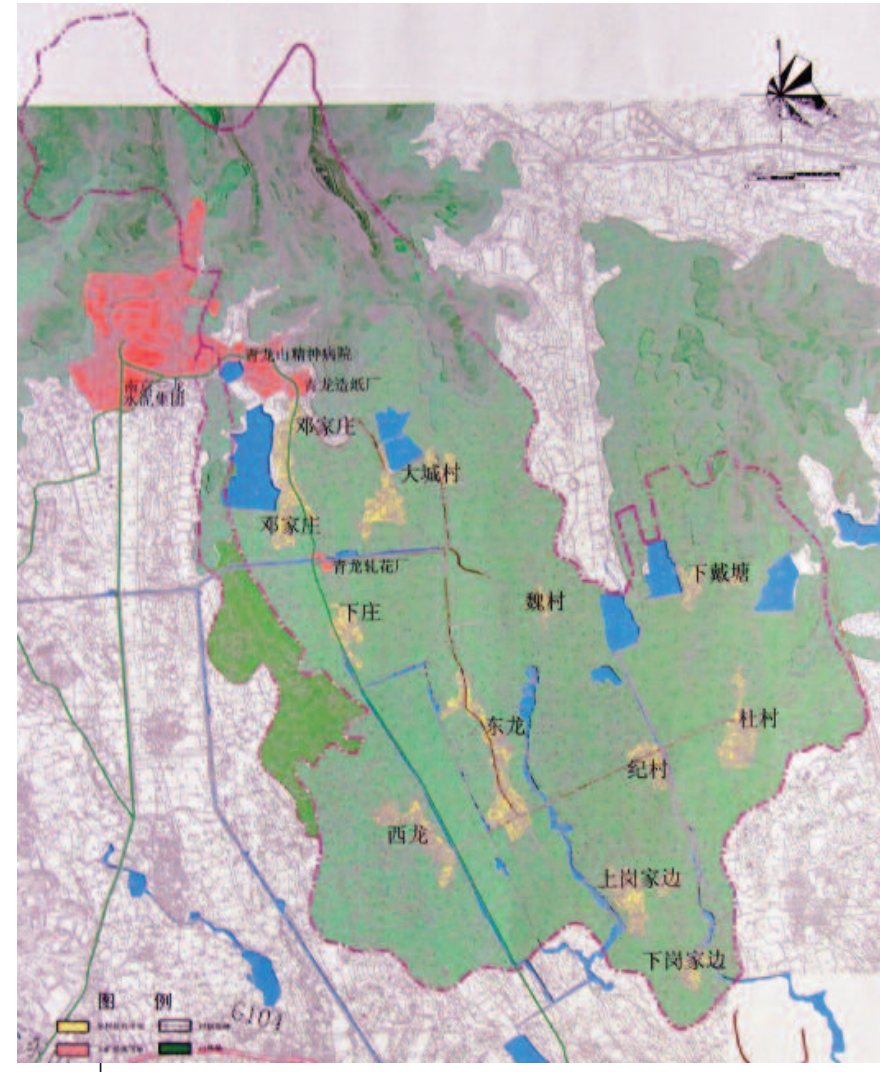

Photo 3 - Qinglong land-use circa 2006; existing villages are shaded in light color. Source: author's photograph of local planning document.

Donglong's status as Qinglong's primary settlement and the site for key public services and administration. For these reasons, its planning and development have been prioritised over other villages.

But the most significant feature of Qinglong's master plan is the stipulation that its original 14 natural villages will be "concentrated" into three settlements based on the largest three existing villages - Donglong (东龙), Xilong (西龙), and Du Cun (杜村) - meaning that 11 smaller villages and hamlets will be demolished and the residents relocated into new housing developments within the larger settlements. ${ }^{(41)}$ One of the key objectives for "concentrating" settlements, of course, is to save land. According to the Qinglong master plan, the total land used for residential settlements will be reduced from 150 hectares to 63 hectares, saving 87 hectares for other uses. ${ }^{(42)} 52$ hectares of this land were designated for development of a new industrial park located to the north of Donglong Village. Another 30 hectares were set aside for expanding the existing small public cemetery. In addition, an area of around 140 hectares of tea plantations adjacent to a large water reservoir in the north-east part of Qinglong was designated for tourism development - including facilities for fishing, sightseeing, and accommodation. ${ }^{(43)}$

Originally approved for implementation in 2006, the Qinglong master plan has subsequently undergone a major round of revision. In the revised version, which appeared in 2010, the industrial zone was expanded to almost double its original size, while the Donglong Village site was extended by an additional $50 \%$. Qinglong officials had to apply to the District government for permission to expand these zones because the changes necessarily encroached on existing farmland.

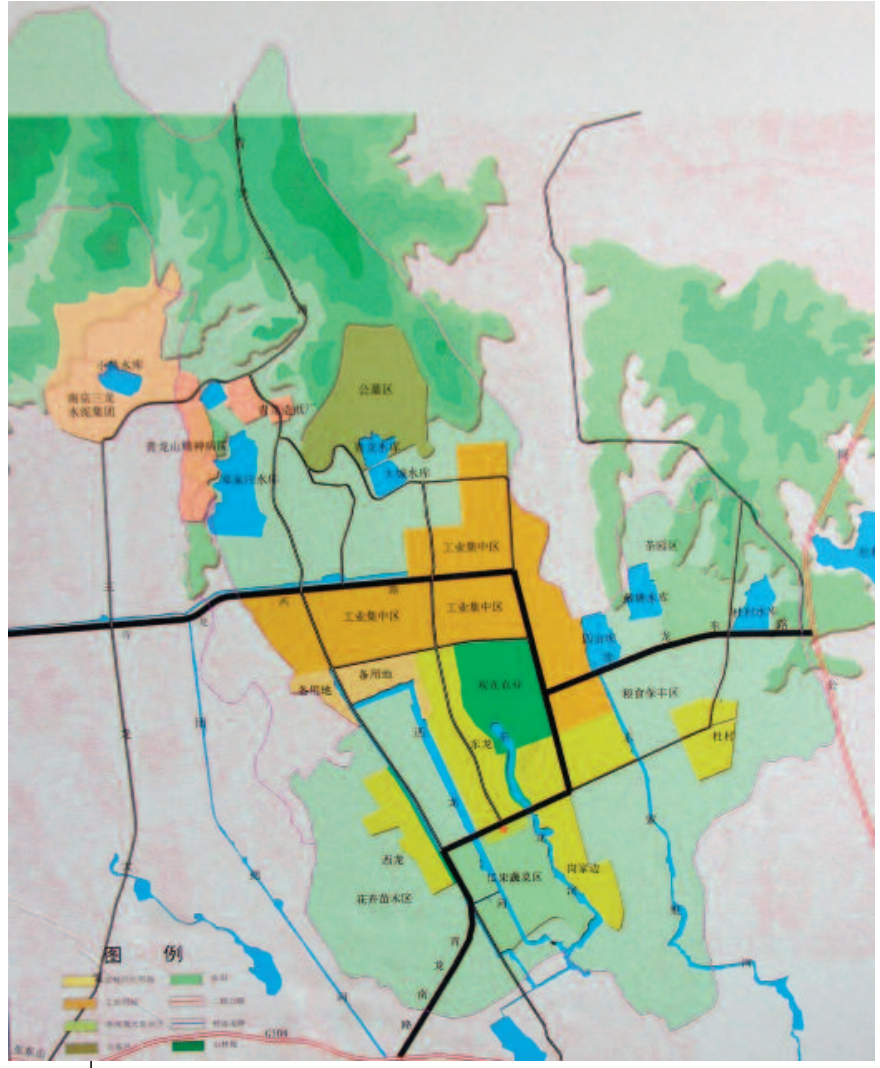

Photo 4 - Projected land-use plan for Qinglong 2020, revised version 2008; proposed residential areas shaded in light color, proposed industry park shaded in slightly dark grey. Source: author's photograph of local planning document.

\section{Renovating Qinglong's environment}

Although the master plan was not formally ratified until October 2006, major efforts to clean up and modernise Qinglong's built environment began in April as soon as it was designated a "high standard trial site." Following provincial guidelines, the Qinglong leadership began tackling key problems associated with village sanitation, pollution, and basic infrastructure. Known as the "six clean-ups and six set-ups" (liuqing liujian 六清六建), this initiative required participating villages to implement six specific projects:

1. Clean up rubbish; set up a rubbish management system;

2. Clean up manure; set up a human and animal waste management system;

3. Clean up straw; set up a comprehensive system for re-using all straw;

4. Clean up waterways; set up a water management system;

5. Clean up industrial pollution; set up a stable and standards-based system;

6. Clean up chaotic construction practices; set up a system for managing village appearance. ${ }^{(44)}$

40. Qinglong Community, Qinglong shequ xin nongcun jianshe guihua (Qinglong Community new countryside construction plan), Nanjing, 2006, p.1.

41. Ibid., p. 10.

42. Ibid., pp. 8-12

43. Ibid., p. 13

44. Jiangsusheng nongcun renju huanjing jianshe he huanjing zonghe zhengzhi: shidian gongzuo fang'an (Jiangsu Province work program to establish trials in rural areas for improving the environment for human habitation and for overall renovation of the environment), Nanjing, 2005. 
By the middle of 2007, Qinglong's leaders were able to report that all six projects had been implemented fully in the three central villages and partially in the other villages, and that as a result, the former "dirty, chaotic, and backward" local environment had been given a "new look." According to their report, they had built 60 new large rubbish bins and employed 16 sanitation staff; they had connected every household to piped water, installed flush toilets in each home, established systems for treating sewerage, and had ensured that all open manure pits had been converted into closed composting systems; they had forbidden the burning of straw and organised ways to re-use it in the vegetable fields and tea plantations, and had cleaned and dredged 15 ponds, $3.8 \mathrm{~km}$ of waterways, and $1.5 \mathrm{~km}$ of floodways - approximately one third of the total. Finally, they had improved the village environment by converting $17.5 \mathrm{~km}$ of village roads from dirt to cement, by the demolition of 11 cow sheds, 145 pig pens, and a range of other so-called "dilapidated or illegal constructions," and by planting around 10,000 trees and $5,000 \mathrm{~m}^{2}$ of grass. ${ }^{(45)}$

Although not directly specified as part of the "six clean-ups," Qinglong authorities decided to eliminate domestic pig-breeding from every village under their jurisdiction. They achieved this by classifying household pigsties, traditionally located in courtyards adjacent to homes, as "dilapidated or illegal constructions," thereby justifying their demolition as part of the program to improve the village's appearance. To forestall opposition, Qinglong's leadership agreed to pay each affected household an annual compensation of 300 yuan per person for "meat expenses." (46)

While the provincial guidelines were silent on the issue of pig breeding, justification for this intervention can be found in central government documents. In their instructions on village renovation, the Ministry of Construction calls for the "separation of humans and domestic animals" (ren chu fenli 人畜分离) (47) on the grounds that keeping animals in residential areas increases the potential for outbreaks of contagious disease and leads to many disputes between neighbours. ${ }^{(48)}$ Such problems can be avoided through implementing a "strict separation of residential zones and production zones, so as to establish concentrated residential areas and concentrated livestock and poultry breeding areas." (49) In this pronouncement we find again the emphasis on functional zoning as a key strategy for re-ordering the rural environment. In this case it not only serves to improve village appearance through removing the unsightly pigsties, but also fosters a shift to a larger-scale mode of production that is seen by authorities as more efficient, hygienic, and scientific.

\section{Creating a new civic centre}

With the launch of the master plan in late 2006, Qinglong moved from an environmental clean-up phase into a new construction phase. Key projects in this phase included development of the new industrial park and the enhancement of public facilities and services in Donglong. In the past, Qinglong residents had to travel to Chunhua or to jiangning for anything more than rudimentary medical treatment or to access most of the welfare benefits or government services. Now they enjoy a full range of community services and welfare facilities much closer to home. These include a newlybuilt community health clinic, a cultural centre, and a community public service counter where local residents can access most welfare and government services with no need to travel farther afield. This service counter is also the site through which new national initiatives such as the rural cooperative health insurance system and the rural minimum living allowance are

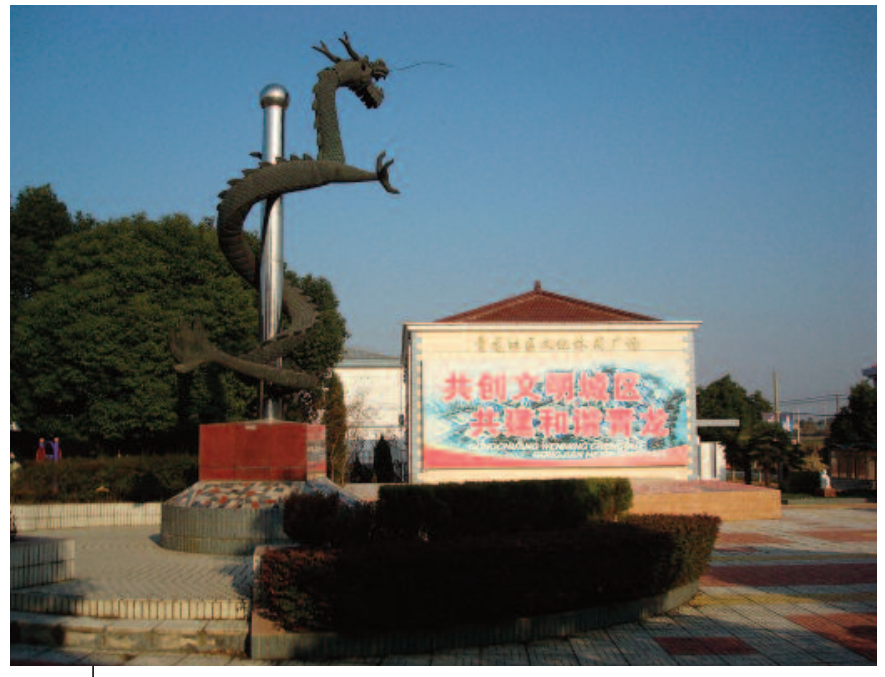

Photo 5 - Dragon Square, Donglong Village 2009.

Source: author's photograph.

\section{administered}

The expansion of village facilities and services is reflected in the physical growth of the village's civic centre. The urban planners have sought to arrange the new facilities into a systematic and logical spatial order based on the underlying principle of functional zoning. Thus, in the second part of the Qinglong master plan, the "Donglong Central Village Short-term Renovation Plan," the planners explain that they have divided Donglong into three zones: the old village zone, the new village zone, and the public service zone; and that one of the key objectives is to redevelop the current village centre into a "lively and fully-functional public service zone." (50)

At the centre of this zone is a 1,200 $\mathrm{m}^{2}$ public "cultural" square. Equipped with a stage at one end, the square can be used for cultural performances and for large-scale village meetings. However, the designers also intend for the space to be used more informally for everyday leisure activities. To this end, around the perimeter of the paved area they have provided shady trees, landscaping, seating, and exercise equipment.

Qinglong's square also serves as a spatial focal point around which a range of other facilities and services are located. Indeed, because of its centrality, the square has been designated as the main location for disseminating information to the public. Along its southern edge, between the square and the footpath that leads from the old village zone towards the cultural centre, the health clinic, and the new village residential area, a long row of glasscovered notice boards have been erected. A wide range of information is provided here, including public health notices, guides to resident services, recent newspapers, reports on community meetings and finances, notices on upcoming cultural events, and educational materials related to wider policies such as family planning. To further underscore its spatial significance as the heart of village life, authorities have installed a large sculpture of a

45. Qinglong Community, Huanjing zonghe zhengzhi gongzuo zongjie (Summary of work undertaken for the overall renovation of the environment), internal unpublished report, 2007.

46. Yulin Zhang, Daoming Ma, and Jianfang Zhu, Chunhua jiyi (Chunhua record), Nanjing, Nanjing University School of Sociology, 2008, p. 93.

47. Ministry of Construction, Guanyu cunzhuang zhengzhi gongzuode zhidao yijian (Guiding views on the work of renovating villages), Beijing, 2005, Section 1.4 .

48. Ibid., Section 2.4

49. Ibid., Section 1.4 .

50. Qinglong Community, Qinglong shequ xin nongcun jianshe guihua, op. cit., pp. 17-18. 


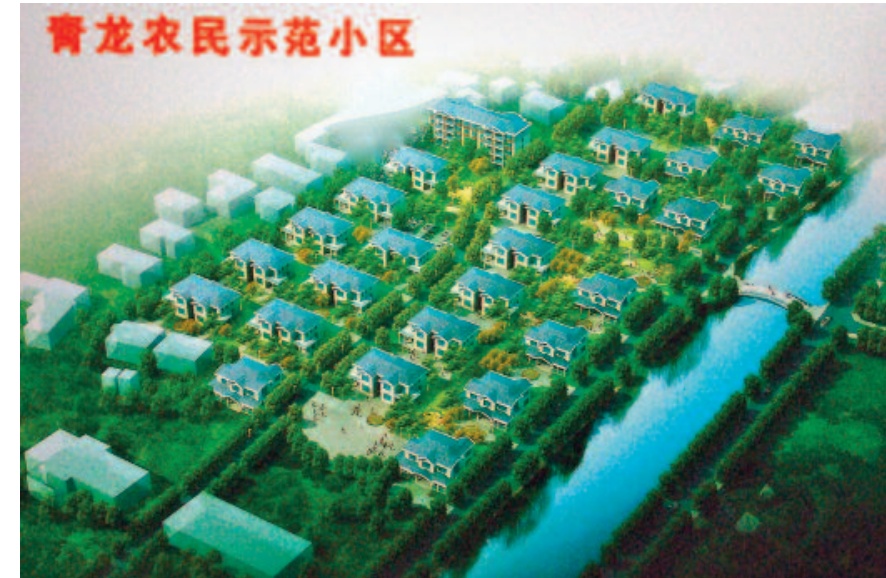

Photo 6 - Artist's impression bird's-eye-view of Longwei xiaoqu, 2008. Source: author's photograph of public display board.

rampant dragon right in the middle of the square. Literally embodying the name of the community - Qinglong, or "green dragon" - this sculpture is apparently intended to symbolise the new spirit of vitality and strength that underpins Qinglong's recent redevelopment and future ambitions.

The other key public facilities are arranged in close proximity to Dragon Square. The cultural centre abuts directly onto the eastern edge of the square, while the community's administrative headquarters, which houses the public service counter, is located opposite the square, on the other side of the main road. The new health clinic and kindergarten are sited just to the east of the cultural centre, on the southern edge of the new village residential zone. A public bathhouse, built some years previously, sits just beyond the northern edge of the square, while across the village road - which forms the western boundary of the square - can be found Qinglong's small commercial strip, including two general stores, two simple restaurants, and a hardware store. Although modest by urban standards, the development of these public facilities significantly improves both the number and quality of services available.

\section{New "village" residential development}

The next stage in implementing the master plan was to commence the program to "concentrate" the original 14 villages into three "central villages." The first to be moved was a small hamlet called Wei Cun, whose 35 households were relocated to a new residential estate (xiaoqu 小区) on a piece of land immediately to the east of Donglong's civic centre. Building work commenced in 2008, and according to local officials, the entire project cost around 19 million yuan. Grants from the City and the District contributed 1.3 million, but the rest was paid over three years by Qinglong Community itself from their collective income of around 15 million yuan per year. In order to encourage the residents of Wei Cun to move, the Community offered houses in the new xiaoqu on the basis of a one-for-one exchange of house area. ${ }^{(51)}$ For example, if their house in the old village was 100 square metres, then the family received 100 square metres of new housing for free. If any families wished to have a larger house in the new development, they could purchase extra space for 1,000 yuan per square metre, which was 300 yuan below the actual construction cost. Costs covered by the Community included all the infrastructure, landscaping, and on-going maintenance of the estate. Services such as gas, electricity, and water are also subsidised in order to keep costs down for the new residents. In moving into the new xiaoqu, villagers did lose most of their former "private plot" land, (52) but they retain all their agricultural land and their share in the Community's collective income. Many villagers also earn income through work in local agriculture or industry.

According to Qinglong's Deputy Party Chief, Wei Cun villagers were consulted in every phase of the planning and development process.

We got every household to select a representative and explained the project to them in detail, then hired a couple of buses to take them to visit some comparatively good rural xiaoqu in other parts of Jiangning where they could talk to the locals about their own experiences in relocation. Afterwards at lunchtime we asked them what they thought. They all said, "Great, we support your plan, let's do it"...Then after we came back we started to design this xiaoqu. It's a rural residential area, it's not for city people. Rural people all need a bit more space; it's what they are used to. During construction, especially when the foundations were being laid, there were always at least three villagers on site to inspect and supervise the work. At that stage they didn't know which house would be whose, but they wanted to make sure that all the construction work was done properly.

The strategy of keeping the village together as a social unit has met with appreciation, as one of the villagers commented in 2011:

Yes, it's the same as before, nothing has changed. It's not like in the city where neighbours don't know each other. Here we all know each other. We're all still the same people living in close proximity and seeing each other all the time. My mother said to me that she would much rather stay where she knows people and can chat and meet up with friends.

Although the new xiaoqu is directly adjacent to the village of Donglong, the planners have sought to maintain a degree of distinctive identity. First, just like an urban xiaoqu, this residential area is enclosed and gated, with a two-meter high fence clearly separating it from the rest of Donglong. Secondly, it has been officially named Longwei xiaoqu (龙魏小区) -combining the "long" from Qinglong and Donglong with the "wei" from Wei Cun - thus symbolising continuity of the old village even as it is appended to a larger settlement. Thirdly, the governance structure of the old Wei Cun hamlet the villagers' small group (cunmin xiaozu 村民小组) - has been maintained in the new location. (53)

Yet at the same time, it is difficult to reconcile continuity with the radical disjuncture in the built environment. Where the old village was an organic sprawl of vernacular buildings from different periods, consisting of houses, sheds, and yards set among fish ponds, vegetable gardens, and orchards, the

51. Only the actual house and kitchen (which in Qinglong is often separate to the main house) were included in these calculations. Yards, sheds, and other outbuildings were not counted.

52. The Chinese term that is normally translated as "private plot" is more faithfully translated as "selfretained land" (ziliudi 自留地). The term derives from the period of collectivised agriculture when the vast majority of farmland was worked collectively. Nevertheless, in this period 5-7\% of land was distributed to individual families to farm for their own use - often to grow vegetables and fruit to supplement the family's diet. After de-collectivisation, all farmland was divided up and contracted to families, but the concept of "private plots" was carried over into the new system and continued to be treated as a separate category of land.

53. Interview with Mr. Gao, 26 October 2011. 
new "village" looks like a little piece of contemporary middle-class suburbia. The neat rows of two-storey, gable-roofed villas set in landscaped gardens and manicured lawns would not be out of place in the suburbs of any modern Western city. However, the neat vision of contemporary middle-class suburbia is somewhat undermined by the realisation that there is no private land within this residential development. There are no enclosed yards and no internal fences of any sort. The homes sit directly in the midst of the landscaped parkland.

The absence of private yards not only runs counter to our understanding of suburbia, it also breaks with long-standing practice in rural China. Traditionally in many parts of China, the archetypal home was sited within a courtyard, or yuanzi (院子). ${ }^{(54)}$ Ideally the yuanzi is fully enclosed, its entrance marked by an ornamental gate, but in practice, the yuanzi can still be functionally present even without physical enclosure. Often it is simply a cluster of structures - houses, sheds, out-buildings - where the family's possessions are stored and arranged. In old Wei Cun, like the other villages of Qinglong, some yards were enclosed and some were not; nevertheless, all of them had a yuanzi of some kind. Functionally, the yuanzi facilitates certain types of familial social interactions. Many yuanzi contain more than one conjugal family unit - often the parents and one or more of their married children (usually but not always sons) will have separate homes within the yuanzi. In this situation, the yuanzi provides a spatial structure to mediate and order the relationships between branches of an extended family unit. The new xiaoqu is not designed to accommodate these kinds of relationships, because each household is distinctly demarcated from every other within an open, transparent and geometrically ordered public space. The yuanzi tends to blur the distinction between inside and outside, as residents move between buildings within the yuanzi for cooking and eating, carrying out chores, feeding domestic animals, and socialising with other family members. In contrast, the xiaoqu is inscribed with a rigid binary spatial code based on a transparent differentiation between inside and outside. Inside the home is private, ${ }^{(55)}$ but as soon as residents walk outside the door they have entered the open public domain. While the xiaoqu itself is an enclosed compound, its enclosure operates at the scale of the "village" rather than the family unit. This is "collective" or "community" space, landscaped and regulated under the management of Qinglong authorities. Unlike in the old village, there is no in-between space, simply a numbered front door that marks the boundary between inside and outside and recodes it as a threshold between private and public.

The loss of the yuanzi is part of a spatial reconfiguration that results both from the imperative to save land and from the desire to modernise rural life. The old Wei Cun occupied 110 mu of land, while the new residential area only takes up about 40 mu. Land has been "saved" through eliminating the yuanzi as well as the vegetable plots, fish ponds, orchards, and animal enclosures. One of the villagers explained these changes in the following way in 2011:

In the old village there is more space and no walls, so you need dogs to protect your place; you also have plenty of space to breed ducks and chickens. But in this enclosed xiaoqu you don't need to worry about safety so you don't need dogs; and there is not enough space now for poultry.

Actually, there is a great deal of open space within the xiaoqu, certainly more than enough to provide areas for poultry raising. What he seems to

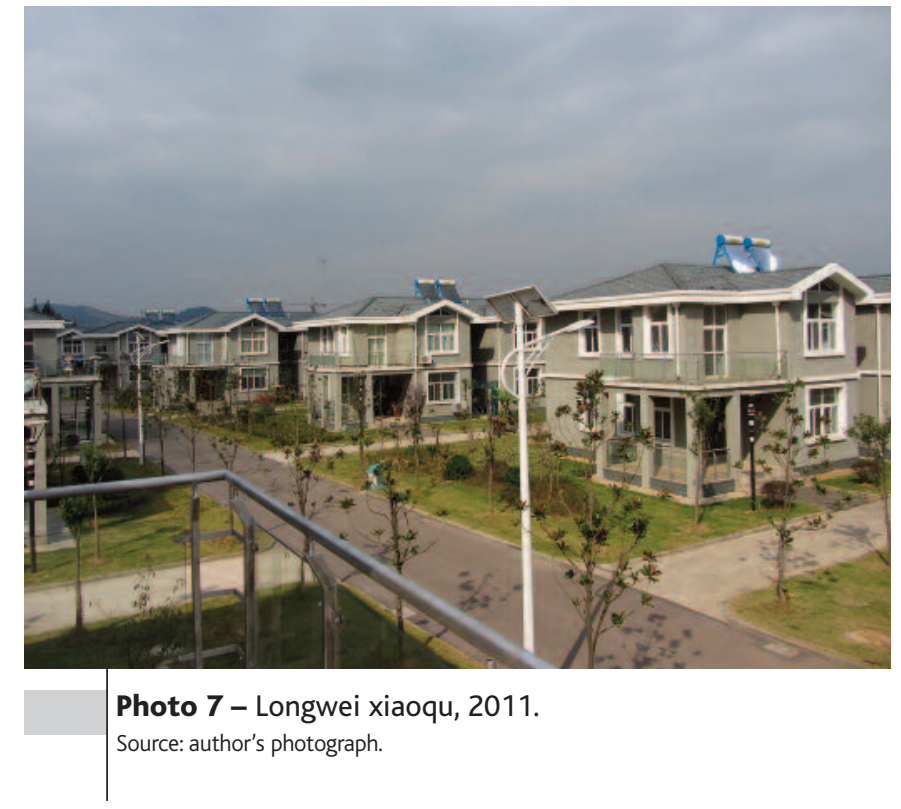

mean is that there is no appropriate space for poultry, nowhere that they belong in the new spatial regime that underpins this urban-style xiaoqu. For if the homes don't have yards, then where could the poultry live?

The modernity of the new "village" is not only embodied in its architectural and spatial forms, and in the exclusion of productive animals, but also through the provision of a full complement of contemporary technologies that previously have been found only in urban residential areas: hot and cold running water, sewerage, cooking gas, and digital broadband cable. Old Wei Cun was not connected to sewers, gas, or communications. The connection of each household to running water through the advent of domestic plumbing replaces communal water supply and public bathing with privatised modes of personal hygienic practice. Meanwhile, the new digital broadband cable connects the residents of Longwei xiaoqu to a vast world of information and entertainment. Of course, villagers formerly had some access to these networks through broadcast television and mobile telephones, ${ }^{(56)}$ but the broadband cable increases the volume and ease of access by many magnitudes: villagers now can watch more than 100 TV channels and view many thousands of internet sites.

For the new residents of Longwei xiaoqu, the implications are both structuring and enabling: the technologies that underpin the form and the functioning of the new "village" circumscribe their everyday lives in significant new ways. At the same time, their connection to these technological networks opens up new possibilities for engagement with, and mobility across, other parts of the network.

However, not every resident of the old Wei Cun is attracted to the apparent benefits of the new xiaoqu and the technologies it embodies. Mr. and Mrs. Guo don't want to move. Although they have been given two units in the new xiaoqu (their son and daughter-in-law have already moved into

54. Ronald Knapp, The Chinese House: Craft, Symbol and the Folk Tradition, Hong Kong, Oxford University Press, 1990.

55. Of course there are different degrees of privacy within different parts of the home; from the less private spaces of the kitchen, the living room, and the dining room to the more private spaces of bedrooms. For an account of transformations in rural home design and its implications for "privacy," see Yunxiang Yan, Private Life under Socialism: Love, Intimacy, and Family Change in a Chinese Village, 1949-1999, Stanford, Stanford University Press, 2003, pp. 112-139.

56. Rachel Murphy, "The Narrowing Digital Divide: A View from Rural China," in Martin King Whyte, op. cit., pp. 166-187. 
one unit) they prefer to stay in their old home of four decades. Even as all the neighbouring homes are demolished around them, they are determined to hold out as long as possible. At first it seemed their main concern was what they believe to be inadequate financial compensation for the fruit trees, fish ponds, and vegetable gardens they have to give up as part of the move. ${ }^{(57)}$ But in my most recent meeting with them it became clear that they have more fundamental objections, as Mr. Guo explained:

There's nothing for us to do in that place. You're not allowed to grow vegetables or raise chickens and ducks there. We're old farmers, not city people or workers... And why should we pay for water and cooking gas when we get those things for free here? We have a well full of fresh mountain spring water and plenty of wood, straw, and chaff for cooking. You even have to pay for the water to flush your shit away over there! (58)

Former neighbours who have already moved into the new xiaoqu are far from sympathetic, suggesting that the Guos are simply greedy and are holding out for more compensation. However, it seems clear that beyond the issues of compensation and the fear of higher costs of living, the Guos are just not attracted to the way of life on offer in the new xiaoqu. Apparently, the lure of modern plumbing, cable TV, cooking gas, and landscaped gardens cannot overcome their deeply entrenched attachment to a familiar if simpler way of life. Ultimately, the apparently utopian aim to integrate urban and rural China relies upon the ability to persuade villagers to give up land and to transform their way of life. While many are no doubt happy to make this shift to an urban-style life, others will resist until dislodged by coercive force.

\section{Conclusions}

My objectives in this paper have been twofold: first I sought to reconstruct the key moves that resulted in urban planning taking a rural turn in China; and secondly I endeavoured to illustrate the momentous implications of this turn through describing the implementation of an actual village "master plan." My interest in the program to Build a New Socialist Countryside, or in rural redevelopment in general, does not lie in the field of political economy. No doubt some readers will feel that I have neglected many details concerning the state/society relations, the political connections, and the funding arrangements associated with this village redevelopment project. However, if I have neglected these questions, it is because I wanted to devote more attention to understanding the actual physical transformations to the village built environment. Thus, my question was not "How did village officials raise the money to build all this stuff?" Rather, it was "What did they build, what were they trying to achieve and how did the transformed built environment impact village life?"

As well as asking some different questions, my research suggests some different conclusions. For example, in their otherwise illuminating study of rural development in Shaanxi and Zhejiang, Ahlers and Schubert reach two conclusions that do not gel with my findings. First, in characterising the program to Build a New Socialist Countryside as a "macro-policy," they argue that it provides only "rough guidelines for implementation while delegating the main work of policy concretization to local governments." (59) My study on the redevelopment of rural built environments, however, demonstrates that this part of the program has been driven by a highly centralised spatial planning regime, which mandates very detailed standards and specifications for design and construction. Secondly, their argument that China's current emphasis on rural urbanisation simply mimics a development model from Europe and industrialised East Asia ignores the specific genealogical processes through which Chinese discourses of urban planning merged with discourses of rural rejuvenation, as described in this paper, to create a unique strategy for rural urbanisation. Illustrated through a case study of the Qinglong master plan, I have shown that while this form of spatial planning enforces a modernist, urban-style vision of the built environment, it is also underpinned by an ethos of continuity, which seeks to hold rural communities together even as their everyday lives are re-inscribed through radical socio-technical interventions.

\section{David Bray is Senior Lecturer in Sociology at the Department of Sociology and Social Policy of the University of Sydney. SSPS Administration, R.C. Mills A26, University of Sydney NSW 2006 (david.bray@sydney.edu.au).}

57. Interview with Mrs. Guo, 24 November 2009. The Guos have around $5 \mathrm{mu}$ of private plot surrounding their home in the old Wei Cun, but will qualify for only $0.2 \mathrm{mu}$ of vegetable land adjacent to the new xiaoqu.

58. Interview with Mr. Guo, 22 July 2012.

59. Anna L. Ahlers and Gunter Schubert, "'Building a New Socialist Countryside' - Only a Political Slogan?", art. cit., p. 36 